\title{
Mateusz Superczyński
}

Archiwum Państwowe w Toruniu

e-mail: msuperczynski@torun.ap.gov.pl

ORCID ID: 0000-0002-8176-412X

\section{nwentarz fary chełmińskiej i jej biblioteki} z XV wieku

\author{
DOI: http://dx.doi.org/10.12775/FT.2017.012
}

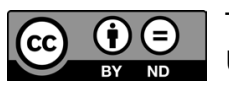

Tekst jest opublikowany na zasadach niewyłącznej licencji Creative Commons Uznanie autorstwa-Bez utworów zależnych 3.0 Polska (CC BY-ND 3.0 PL).

Mgr Mateusz Superczyński jest pracownikiem Archiwum Państwowego w Toruniu; absolwent kierunku Archiwistyka i Zarządzanie Dokumentacją na Uniwersytecie Mikołaja Kopernika w Toruniu (dalej: UMK). W czasie studiów był członkiem zarządu Studenckiego Koła Naukowego Archiwistów. Otrzymał wyróżnienie za pracę licencjacką pt. „Źródła do dziejów przedmieścia Torunia - Mokre" w konkursie SAP im. Ryszarda Mienickiego na prace dyplomowe o tematyce archiwalnej oraz I nagrodę za pracę magisterską pt. „Źródła do dziejów przedmieść Torunia od XIII w. do 1793 r." w konkursie Towarzystwa Miłośników Torunia na najlepsze prace dyplomowe o tematyce toruńskiej. W latach 2012-2014 był pracownikiem Archiwum Uniwersyteckiego UMK. Członek Stowarzyszenia Archiwistów Polskich i Towarzystwa Miłośników Torunia. W chwili obecnej przygotowuje pod kierunkiem prof. Janusza Tandeckiego dysertację doktorską zatytułowaną: „Kancelaria i archiwum miasta Chełmna w okresie przedrozbiorowym (XIII w. - 1772 r.)".

łowa kluczowe: Chełmno, biblioteka przykościelna, inwentarz, kopiariusz, fara chełmińska

treszczenie. Artykuł niniejszy prezentuje edycję nieznanego szerzej dotychczas inwentarza fary chełmińskiej i wykazu księgozbioru biblioteki farnej z XV w., które znajdują się w księdze miejskiej Chełmna - kopiariuszu przywilejów i dokumentów, założonej przez pisarza Konrada Bitschina w 1431 r. Przekaz źródłowy daje obraz biblioteki fary chełmińskiej jako ośrodka kultury w XV-wiecznym Chełmnie. Pozwala także na porównanie trzech zachowanych spisów księgozbiorów średniowiecznego Chełmna, a więc z klasztoru Franciszkanów z XIII wieku, biblioteki farnej i zrekonstruowanego spisu biblioteki Braci Wspólnego Życia z końca XV stulecia, które pochodzą z różnych okresów i odzwierciedlają przemiany w duchowości, teologii i zainteresowaniach naukowych ówczesnych elit intelektualnych miasta. Podczas gdy księgozbiory biblioteki franciszkanów czy farnej oddają ducha średniowiecznej scholastyki czy nominalizmu, to wydania, które posiadali Bracia Wspólnego Życia, zwiastują nadejście humanizmu. Odnotowane przez pisarza miejskiego tytuły, mimo zniekształceń, pozwalają także na identyfikację i odnalezienie wśród nich fundamentalnych dla średniowiecznej teologii, liturgii, historii i filozofii dzieł. 
W Tajnym Archiwum Pruskim w Berlinie-Dahlem przechowywana jest jedna z ksiąg miejskich Chełmna - kopiariusz dokumentów i przywilejów, założony przez pisarza Konrada Bitschina w 1431 r. ${ }^{1}$ Rękopis ten, o tytule "Colmische privilegia und Gewichtten, Huebenmas, Muntz und Pflueg getraidicht allerlei Arten von Drillkun und handwercks-Zunften. Item Magdeburgische gehalte Antworten aufnanderschiedtliche Fragen. Ab Anno 1431 zuesamgetragen und verfasset" zawiera odpisy i kopie najważniejszych przywilejów, dokumentów, wilkierzy oraz statutów chełmińskich, w tym dokumentów dotyczące uposażeń kościoła farnego oraz jego inwentarze. Na szczególną uwagę zasługuje nieznany szerzej inwentarz fary chełmińskiej i jej biblioteki spisany w latach 1436-1452, który m.in. umożliwia rekonstrukcję księgozbioru biblioteki farnej w Chełmnie².

Biblioteki przykościelne i przyklasztorne spełniały ogromną rolę w kształtowaniu ośrodków kulturalnych i naukowych w średniowiecznych miastach. Informacji o księgozbiorach przykościelnych średniowiecznego Chełmna posiadamy niewiele. Podstawowym źródłem wiedzy o istnieniu danego księgozbioru i jego stanie w danym okresie są inwentarze lub katalogi. Badacze w ostatnich latach skupiali się szczególnie na średniowiecznych księgozbiorach mieszczących się w klasztorach w wielkich miastach pruskich. Warto tu przytoczyć choćby prace Wiesławy Kwiatkowskiej, która omówiła biblioteki przyklasztorne franciszkanów i dominikanów w średniowiecznym Toruniu ${ }^{3}$. Osobny artykuł poświęcono także księgozbiorowi franciszkanów chełmińskich, gdzie opisano najstarszy wykaz książek biblioteki konwentu z XIII w. ${ }^{4}$ Spis ten wchodzący w skład pergaminowego kodeksu przechowywanego w Bibliotece Narodowej w Warszawie świadczy o zakładaniu bibliotek przyklasztornych i przykościelnych już w pierwszych dziesięcioleciach istnienia Chełmna. W księgozbiorze franciszkanów chełmińskich znalazły się dzieła fundamentalne w zakresie prawa kanonicznego, jak choćby Concordia discordantium canonuma autorstwa Gracjana, komentarze do Pisma Świętego doktorów kościoła, np. Grzegorza Wielkiego (540604), opracowania Pisma Świętego autorstwa Piotra Rygi (zm. 1209), kanonika regularnego z Reims, dzieła o tematyce typowo liturgicznej, np. Honoriusza Augustodunensis, powstałe w początkach XII w., ale także traktaty teologiczne autorstwa papieża Innocentego III: Item liber Innocencii tercii de missarum misteriis, czy też dzieła historyczne, jak choćby Historia Iherosolimitana wydana w początkach XII5.

Innym ośrodkiem kulturalnym i naukowym w średniowiecznym Chełmnie posiadającym własny księgozbiór biblioteczny było Zgromadzenie Braci Wspólnego Życia, które od ok. 1473 r. posiadało w mieście swój dom i szkołę ${ }^{6}$. Wspólnota

\footnotetext{
Geheimes Staatsarchiv Preussischen Kulturbesitz (Berlin-Dahlem) (dalej: GStA PK) XX. Hauptabteilung (dalej: HA), sygn. Ordensfolianten (dalej: OF) 83.

2 Ibidem, s. 122-125.

3 W. Kwiatkowska, Średniowieczne księgozbiory franciszkanów i dominikanów toruńskich jako świadectwo ich kultury umysłowej i możliwości oddziaływania na środowisko mieszczańskie, Toruń 1991 (mps rozprawy doktorskiej w bibliotece Biblioteki Instytutu Informacji Naukowej i Studiów Bibliologicznych Uniwersytetu Warszawskiego); eadem, Średniowieczna biblioteka klasztoru franciszkanów w Toruniu, Folia Toruniensia, t. 1: 2000, s. 9-30.

4 J. Kaliszuk, Spis książek klasztoru franciszkanów w Chełmnie z drugiej połowy XIII wieku, Studia Źródłoznawcze, t. 47: 2009, s. 96-108.

Ibidem, s. 100-104.

6 Z. H. Nowak, Dzieje tak zwanej Akademii Chełmińskiej, [w:] Dzieje Chełmna. Zarys monograficzny, red. M. Biskup, Warszawa 1987, s. 134, idem, Bracia Wspólnego Życia i ich szkoła w Chełmnie (1473-1536/1545), Zapiski Historyczne, t. 52: 1987, z. 4, s. 53-77.
} 
założona przez Gerarda Groota w latach 80. XIV stulecia była organizacją powstałą na gruncie odnowy kościoła u schyłku średniowiecza. W Chełmnie posiadała, oprócz swojej szkoły opartej na siedmiu sztukach wyzwolonych, także bibliotekę i najprawdopodobniej drukarnię ${ }^{7}$. Na podstawie prób rekonstrukcji biblioteki Braci Wspólnego Życia podjętych przez Elizę Szandorowską można dostrzec występowanie w niej ksiąg o tematyce teologicznej czy liturgicznej gromadzonych już w duchu odnowy kościoła późnośredniowiecznego, jak choćby dzieło Tomasza à Kempis O Naśladowaniu Chrystusa (Imitatio Christi) czy prace współczesnych autorów, np. humanisty niemieckiego Jana Reuchlina (1455-1522). Coraz większą rolę pełniły także dzieła myślicieli i autorów antycznych, czego przykładem może być De officiis Cycerona ${ }^{8}$. Obecność takich pozycji w bibliotece wspólnoty chełmińskiej Braci Wspólnego Życia świadczy o stopniowym zwiększaniu się w niej od początku XVI wieku nurtów humanistycznych. Mimo rozwoju i dobrej renomy, szkoła Braci Wspólnego Życia, która urosła do rangi silnego ośrodka humanistycznego w Prusach, z powodów materialnych podupadła. Ostatecznie także sami Bracia opuścili Chełmno pod koniec lat $30 . \mathrm{XVI}{ }^{9}{ }^{9}$

Biblioteka fary chełmińskiej, z racji późniejszej budowy tego kościoła, musiała powstać nieco później niż biblioteki zgromadzeń zakonnych, takich jak franciszkanie, choć pierwsze księgi potrzebne do sprawowania liturgii mogły być w niej gromadzone już od końca XIII stulecia. Być może służyła ona działającej przy kościele parafialnym szkole miejskiej, o której dowiadujemy się ze wzmianek z początku XIV w. ${ }^{10}$ Zarząd nad biblioteką, podobnie jak nad całym majątkiem, uposażeniem kościoła parafialnego, a więc jego dobrami i gruntami spoczywał w rękach urzędnika rady miejskiej zwanego witrykiem. Urzędnik ten uczestniczył w aktach przekazywania darowizn i fundacji na rzecz kościoła parafialnego i jego altarii, prowadził rachunki fary i zarządzał jego majątkiem. Z wpisu do księgi sądowej miasta Chełmna z roku 1373 dowiadujemy się, że do obowiązków witryka należało także dbanie o stan ksiąg liturgicznych fary chełmińskiej. Na podstawie tej noty wiadomo, że witryk miejski Konrad Palzad na naprawę księgi mszalnej wpłacił 3 grzywny ${ }^{11}$. Z innej wzmianki, tym razem z księgi czynszów fary chełmińskiej, którą prowadził witryk, dowiadujemy się o usługach naprawczych i introligatorskich na rzecz fary, które świadczyła domniemana oficyna drukarska Braci Wspólnego Życia12.

\footnotetext{
E. Szandorowska, Tajemnicza oficyna drukarska XV wieku, Rocznik Biblioteki Narodowej, t. 3: 1967, s. 321-346; eadem, Czy w Chełmnie nad Wisłą drukowano inkunabuły?, ibidem, t. 4: 1968, s. 23-46, Księga czynszów fary chełmińskiej (1435-1496), wyd. J. Tandecki, Z. H. Nowak, Toruń 1994, s. X.

8 E. Szandorowska, Biblioteka i pracownia introligatorska Braci Wspólnego Życia w Chełmnie. Próba rekonstrukcji, Rocznik Biblioteki Narodowej, t. 9: 1973, s. 265-285.

9 Z. H. Nowak, op. cit., s. 138-139.

10 Ibidem, s. 129 ,

11 Das Kulmer Gerichtsbuch 1330-1430. Liber memoriarum Colmensis civitatis, bearb. von C. A. Lückerath und F. Benninghoven, Köln 1999, nr 17: Notandum, quod Conradus Palzod protunc vitricus ecclesie dedit coram nobis consulibus tres $\mathrm{mr}$. do ... Sydensuancz ad persolvendum et optinendum librum missarum ad Fredericum campanatorem comparatum tali modo, quod ipso domino Bycolao decedente liber antedictus ecclesie parrochiali debet divinari circa eandem perpetuis temporibus permanendo. Actum anno Domini ut supra.

12 Księga czynszów fary chełmińskiej, nr 261: Zcu gedencken, das dy bruders aws der bruderhaws gebessert hatten und gebunden etliche bucher der kirchen zcugehorende, alze: eyne agenda, eyn collectarium, eyn missal, eyn psaltarium und eyn anthiphonarium, dovor gab man en von der kirchen gelde summa $71 / 2 \mathrm{mr}$. $4 \mathrm{sc}$. Actum feria 3 ante Lucie XCl anno [6 XII 1491].//
} 
Inwentarz fary chełmińskiej i spis ksiąg jej biblioteki znajdujący się w omawianym kopiariuszu sporządził pisarz miejski i witryk w obecności burmistrza i jego kompana. Przekaz źródłowy załączony do niniejszego artykułu powstał w kilku etapach. Pierwszą jego część stanowi inwentarz sprzętów liturgicznych fary chełmińskiej z roku 1436 zredagowany przez pisarza Konrada Bitschina w obecności burmistrza Koniga i witryka Bartłomieja. Na końcu tej części inwentarza, pod nagłówkiem „Kirchenbuchern” zapisano wykaz ksiąg liturgicznych. Z kolejnego nagłówka możemy wywnioskować, że inwentarz był aktualizowany i uzupełniany w następnych latach, m.in. w 1441 r. Mimo że w wykazie ksiąg liturgicznych wyraźnie zaznaczono, że wchodzą one w skład biblioteki (in librarien), to właściwy spis księgozbioru został sporządzony 20 grudnia 1451 r. najpewniej przez pisarza Jakuba Schoensee w obecności burmistrzów i witryka Michała Zygmunta. Warto dodać, że dukt pisarza Jakuba dostrzec można w starszych fragmentach inwentarza, w licznych dopiskach pod kolejnymi pozycjami.

Spis księgozbioru fary chełmińskiej zawiera łącznie 47 pozycji, na które składają się popularne w średniowieczu dzieła o tematyce teologicznej, liturgicznej, z zakresu prawa kanonicznego, a także historyczne i hagiograficzne. W przeciwieństwie do typowych spisów księgozbiorów przyklasztornych, w których nie uwzględniano wykorzystywanych do liturgii ksiąg, w inwentarzu biblioteki fary chełmińskiej zawarto także księgi tego typu. Z racji zniekształconych przez pisarza tytułów poszczególnych pozycji, ich pełna identyfikacja nastręcza liczne trudności. Największą grupę w spisie stanowią wszelkie teksty Pisma Świętego zarówno ze Starego Testamentu, jak i Nowego z komentarzami np. Corpus Ewangelicum glosatum, Glosa super epistulas, Epystule Pauli glosate, Genesis, Exodiis, Lemitiacus, Numeri dictonomnii, Josue, indictum Ruth et interpretationes Ebra, Johanni psalterium beati Jeromini. Do ważnych tytułów należą prace doktorów Kościoła i ich komentarze teologiczne np. Augustinus de Ankona super Mathie - zapewne interpretacje Augustyna z Ankony żyjącego w latach 1243-1328 ${ }^{13}$, a także Symbolus magistri Johannis de Marienwerder autorstwa zakonnika krzyżackiego i teologa Jana z Kwidzyna (1343-1417), który spisał życiorys bł. Doroty z Mątów ${ }^{14}$. Do fundamentalnych tytułów z zakresu historii należą Scolastica Hystoria - XII-wieczny podręcznik historii biblijnej autorstwa Piotra Comestora ${ }^{15}$, jak również Cronica Romanorum pontificum et imperatorum ac de rebus in Apulia gestis - XIII-wieczna kronika biskupów i cesarzy rzymskich napisana przez nieznanego $z$ imienia mnicha $z$ klasztoru Santa Maria della Ferraria ${ }^{16}$. Do interesujących tytułów należą choćby Tractatus rabi Samuelis tamen errares Judeorum - traktat mistrza Samuela dotyczący trwania Żydów w błędzie i grzechu, który ukazał się w języku łacińskim w 1335 r., wielokrotnie wydawany w następ-

${ }_{13}$ A. Wielomski, Teokracja ekstremistyczna Augustyna z Ankony, Studia Erasmiana Wratislaviensia, t. 5: 2011, s. $69-86$.

14 Jan z Kwidzyna, Żywoty Doroty z Mątów, tłum. J. Wojtkowski, Lublin 2011.

15 M. J. Clarck, The Making of the Historia Scholastica (1150-1200), Studies and Texts, 198, Pontifical Institute of Medieval Studies, 2016.

${ }^{16}$ L. Lozzi Gallo, Chronica Romanorum pontificum et imperatorum ac de rebus in Apulia gestis [online], [dostęp 17 | 2017]. Dostępny w World Wide Web: http://referenceworks.brillonline.com/browse/encyclopedia-of-the-medieval-chronicle/. 
nych wiekach ${ }^{17}$, a także Questiones super quatuor libros sententiarum - dzieło filozoficzne średniowiecznego nominalisty Marsyliusza z Inghen (1340-1396) ${ }^{18}$. W księgozbiorze fary nie mogło zabraknąć dzieł hagiograficznych, jak choćby Vita sancti Yvonis, et glosa super per natura, które napisał Goscelinus Cantauriensis (1082-1100 $)^{19}$. Do pozycji o charakterze encyklopedycznym należy kompendium wiedzy teologicznej Hugona Argentinensis (1200-1268): Compendium theologicae veritatis. Cum Tabula Thomae Dorniberg, mylnie przypisywane autorstwu Alberta Wielkiego ${ }^{20}$. W wykazie znalazł się też dość zniekształcony przez pisarza tytuł pracy Alberta z Brescii (1195-1251): Liber consolationis et consilii (Ksiega pocieszenia $i$ rady $)^{21}$. Jest to praca o tematyce społecznej traktująca o zjawisku zemsty w mieście. Oprócz tych ksiąg, dużą część księgozbioru stanowiły różnego rodzaju brewiarze, psałterze i księgi liturgiczne.

Inwentarz, którego edycję dołączono do niniejszego artykułu jest cennym przekazem źródłowym z racji jego przydatności do badań nad dziejami średniowiecznych bibliotek i księgozbiorów. Źródło daje także obraz biblioteki fary chełmińskiej jako ośrodka kultury w XV-wiecznym Chełmnie. Pozwala także na porównanie trzech zachowanych spisów księgozbiorów średniowiecznego Chełmna, a więc z klasztoru Franciszkanów z XIII w., biblioteki farnej i zrekonstruowanego spisu biblioteki Braci Wspólnego Życia, które pochodzą z różnych okresów i odzwierciedlają przemiany w duchowości, teologii i zainteresowaniach naukowych ówczesnych elit intelektualnych miasta.

Przy opracowaniu edycji inwentarza posiłkowano się projektem instrukcji Adama Wolffa ${ }^{22}$ oraz uwzględniono uwagi instrukcji Waltera Heinemeyera ${ }^{23}$. Zgodnie z tymi wskazówkami literę „u” pisano, uwzględniając jej wartość fonetyczną jako „V”. Wielką literą zapisano imiona, nazwiska, miejscowości i określenia najważniejszych urzędów. Tytuły ksiąg mimo zniekształceń pozostawiono w oryginalnym brzmieniu.

\section{Inwentarz fary chełmińskiej i biblioteki}

[s. 122] Czu wissen das im jare Cristi XIIII ${ }^{c}$ XXXVI am donerstage Borchardi [11 II 1436] der Rath hat lassen besehen und beschreiben der kirchen gerethe durch herr Konig Burgermeisters compan und Bartholomeum Kirchvater und Conrad den Statschreiber, doselbist dis nochgeschrebe gesmeide und gerethe ist befunden.

17 S. Marochitanus, A. Buenhombre, J. Radlinski, Prawda chrzescianska od nieprzyiaciela swego zeznana, to iest Traktat rabina Samuela pokazuiacy bledy zydowskie okolo zachowania prawa Moyzeszowego, y przyiscia Messyaszowego, ktorego Zydzi czekaia, Lublin 1753.

18 Marsilius of Inghen, Quaestiones super quattuor libros Sententiarum, Vol. 2: Super primum, quaestiones 8-21, ed. G. Wieland et al., Studies in the History of Christian Thought, Vol. 88, ed. M. Santos Noya, Leiden, 2000.

19 Vita sancti Yvonis episcopi persae in anglia depositi et trium eius sociorum auctore goscelino (Apud Bolland, Acta Sanctorum, Junii tom II, die 10, pag. 287) [online], [dostęp 17 I 2017]. Dostępny w World Wide Web: http://www.documentacatholicaomnia.eu/02m/1082-1100,_Goscelinus_Cantauriensis,_Vita_Sancti_Yvonis_Persae_Episcopi,_MLT.pdf /.

$20 \mathrm{H}$. Argentinensis, Compendium theologicae veritatis. Cum Tabula Thomae Dorniberg, Ulm 1478-1481.

21 Albertano de Brescia, Llibre de concolacio i de consell, Barcelona 1965.

22 A. Wolff, Projekt instrukcji wydawniczej dla pisanych źródeł historycznych do połowy XVI wieku, Studia Źródłoznawcze, t. 1: 1957, s. 155-184.

${ }^{23}$ Richtlinien fur die Edition landesgeschichtlicher Quellen, hrsg. von W. Heinemeyer, Marburg-Koln 1978. 
folia Item 1 silbern burchsse zum Sacramentum.

toru Item 3 silbern neppihen in derselben burchsen.

niensia Item silbern ampullen.

Item 12 keliche. <Item 1 von Salendorff, eynen Item von herr Hanus Matczke, eyne. Item eynen kelich dy frauwe von Salendorff. Item eynen herr Bartholomeus.> Item 3 kleyne silbern Crucze.

/-Item 1 silbern handt Stanislai.-/

Item 2 silbern cronen.

Item 1 silbern Melchisedeth.

Item 12 corporalia mit futern.

Item 3 corporalia ane futern.

Item 7 pallen.

Item 9 meydechen.

Item 2 meydechen bey der buchssen des firmament, $<7$ mit peilyn, 7 by den sacirent.>

Item ${ }^{24 a}$ eyn gehafft tuch mit silbern spangen.

Item eyn syden duch mit 30 ungulten knouffeln.

Item 2 mentell Marie mit silbern spangen.

Item eyn syden tuch uff das hewszechen irlen.

Item 2 fenchen czum irlen.

Item eyn seyden spolium, item noch eyn seyden tuch.

Item 1 sylbern nochfass Item 1 schon sylbern obirgalter umbe $\left[\ldots{ }^{25 b}\right]<$ Nicolao dem schulmeister.>

Item dis vorgeschreben und nachgeschrebene gerethe, ist allsampt geentwert uff den obengeschrebene tag, do her antrat, am die Bloghenye, ane 7 keliche und eyn kleyn krutcze und die 2 silbern cronen, die silbern handt, und 4 corpalia das haben die vorgeschreben herr behalden in kasten.

Item in deme ledechin do das heyligethum eyne ist do ist eyne das Heilige Holtcz von alden ${ }^{26 c}$ hawse.//

[s. 123]

Item 4 hoistell rogke mit $<36>$ knopfehand eyn von dy andern 2 haben 6 knopfel. Item 8 korszappen.

Item 8 ornatus ad festum totus duplices /-dy eyne mit 1 gelde knofe.-/ Item 10 ornatus mit allem gerethe, duplices.

Item 12 ornatus semiduplices.

Item 9 ornatus ferial.

Item eyn weys ornatus in der fasten.

24 a Obok na marginesie <vitricus>.

25 b Wyraz nieczytelny.

26 c Obok /-vom- $/$. 
Item 3 ledige alben. Item 2 ledige ornatus .

Item 4 antipondia duplici.

Item 3 antipendia semiduplici. <item 4 antypendia diaconis duplicis.>

Item 4 antipendia 9 literom.

Item 14 umbralia.

Item /-8-/ korrogenkell 13. <Item 2 hot dem pfarrer.>

Item 5 pallen, 6 hant tucher. <Item 1 cleyne antipendia ken Podigest.> Item eyn hunger tuch, 15 fasten tucher, velamina.

Item vier altarien mit irem czubehorzugen tegelichen, <Item 1 stul koppel.> Item 3 stulteppte. Item 4 altare teppte.

Item 1 sedeldecke, 2 pfoell, 2 kussen.

Item 1 syden kussen zum cruczen und 1 tuch.

Item 5 par phanen.

Item 4 grosse par luchter. Item eyn kleyn par luchter.

Item 4 kleyne kuppern, eltern luchter.

$<$ item 1 sprengefasse.>

<Item 1 thurbulern.>

<Item 2 shusslen.>

Item 1 hantfass ${ }^{27 d}$, eyn messunge kessil.

Item eyne kanen, eyn grosse ampulle. Item 2 par grosse ampullen.

Item 2 par kleyne ampullen.

Item 2 laternen. Item 2 schellen tum gratione czugenen.

Item 1 ledechen mit reliquien. Item 2 taffeln mit reliquien.

Item eyn viaticus eltorsteyn.

Item 3 missalia.

Item 2 breviarem in dem sarvistien. Item 1 brevier vor dem Sacramentum.

Item eyn neuwe buch von unsir lieben Frawen. <Item 2 vigilien.>

Kirchenbuchern

Item drey gradalia, 2 antyphonalia, 2 prosaria, 2 legenden, 2 salteren.

Item 4 pertes antyphonarien. Item 2 sperialia novarum historiarum.

Item 3 agenden, 2 collettarem, 1 venitalem, 2 vigilien.

Dis nochgeschreben gerethe hot der Burgermeister her Bartholomeus Rossenick gantcz beseheen mit dem Kirchenvater herr Peyss von Wedir geantwortet mit den czedel den unsere sancti [..... ${ }^{28}$ ] den glockner an den mitwoche vor Elizabeth Anno etc XLI [1 XI 1441]//

[s. 124]

Item diese nachgeschreben bucher doselbist sint beschreben in der librarien

Primo uff den ersten pulpite 1 brevirer.

Item 1 misalle.

27 d U góry wyraz < Vasa

28 e Wyrazy nieczytelne. 
Item 1 saltern mit den glosen.

Czu wissen ist das die stadt gelegen hot anno etc. XLVI [1446] eyn buch in papyr geschrebene Nicolaus delyra super Johannem her Conradt Mager und das selbige buch hot her geloubet in Breter czu Lynden uf das man denne in dy lybria mag schaffen.

Item disse nochgeschreben buchir dy in der lybrien legen synt beschreben bey den herren: her Hannos Matczken Burgermeistern, herr Bartholomeus seyn compan her Lorentcze Czeytcze der dreen Burgermeister und herr Michels Sigemundes Kyrchen Vaters geczeyten Anno etc. LI ${ }^{\text {sten }}$ Jore am obende Thome Apostoli. [20 XII 1451]

[1] Primo corpus Ewangelicum glosatum. [2] Item quatuor libri regum per ali pomnium [?]. [3] Item Essdy Thobye, Judyth Hester. [4] Item Johanni psalterium beati Jeromini. [5] Item quoque libri Salomonis. [6] Item Jeremias, Barath, Ezechel et Daniel. [7] Item Osee, Joheel, Annos, Abdyas, Jonas, Micheel, Naym, Abbatus cum quatuor. [8] Item Genesis, Exodiis, Lemitiacus, Numeri dictonomnii, Josue, indictum Ruth, et interpretationes Ebra. [9] Item Augustinus de Ankona super Mathie. [10] Item Hugwycius sed alphabetum. [11] Item textus quarti sumarum et vita beate Elisabeth cum diversum materiis. [12] Item Bryto et speculum punctator et mundae. [13] Item epystule Pauli glosate. [14] Item Machabeorum. [15] Item Scolastica Hystoria. [16] Item Actus Apostolorum depoka. [17] Item glosa spalterii. [18] Item eyn dutsche Spalter. [19] Item Quadragesimale. [20] Item eyne dutsche Byblie. [21] Item tractatus rabi Samuelis tamen errares Judeorum. [22] Item vita sancti Yvonis, et glosa super per natura [?]. [23] Item exterpta revelationi Brygytte et de infantia salvatorum. [24] Item cronica romanorum pontificum et imperatorum. [25] Item passionale. [26] Item Jacobimus de tempore. [27] Item liber originalium diversorum dictorum. [28] Item postilla de tempore. [29] Item Augustinus de Civitate de [?]. [30] Item symbolus magistri Johannis de Marienwerder. [31] Item collecta circa tres libros puarum. [32] Item glosa super epistulas. [33] Item// [s. 125] questiones super quatuor libros sententiarum. [34] Item liber consilii et consolatoris. [35] Item summa pysana. <[36] Item succus estimalis. [37] Item succus hiiemalis. [38] Item summa gotfridi. [39] Item manipulus florum. [40] Item distimonio Mauricy. [41] Item libri summe casuum. [42] Item questiones super quator libros sententiarum. [43] Item compendium theologyce veritatis. [44] Item psalteum cum ex posicione. [45] Item 8 missale. [46] Item 8 breviarium. [47] Item consessionale>.

Disse nochgeschreben buchir hat Laurencius Iserlo der schulemeister do her wart ingeweyset anno etc. LIIte [1452]

Primo eyn gradale de sanctis und de tempore.

Item eyn antiphona in de sanctis et de tempore.

Item 1 hystoriale de Beate Virginis.

Item 2 saltern. 
Item 2 legende de sanctis und de temporis. Item 2 antyphonaria heymale und Estinale. Item 1 gradale.

\section{Bibliografia}

Albertano de Brescia. 1965. Llibre de concolacio i de consell. Barcelona: Editorial Barcino.

Argentinensis, Hugo. 1478-1481. Compendium theologicae veritatis. Cum Tabula Thomae Dorniberg. Ulm: Johann Zainer.

Clarck, Mark. 2016. "The Making of the Historia Scholastica (1150-1200)", Studies and Texts, 198, Pontifical Institute of Medieval Studies.

Gallo, Lozzi. Chronica Romanorum pontificum et imperatorum ac de rebus in Apulia gestis [online], [dostęp 17 I 2017]. Dostępny w World Wide Web: http:// referenceworks.brillonline.com/browse/encyclopedia-of-the-medieval-chronicle/.

Heinemeyer von Walter hrsg. von, 1978. Richtlinien für die Edition landesgeschichtlicher Quellen. Marburg-Köln: Selbstverlag desGesamtvereins der Deutschen Geschichts- und Altertumsvereine.

Jan z Kwidzyna. 2011. Żywoty Doroty z Mątów, tłum. J. Wojtkowski. Lublin: Wydawnictwo KUL.

Kaliszuk, Jerzy. 2009. „Spis książek klasztoru franciszkanów w Chełmnie z drugiej połowy XIII wieku". Studia Źródłoznawcze 47: 96-108.

Kopiariusz przywilejów i wilkierzy miasta Chełmna 1431 r. XX. Hauptabteilung sygn. Ordensfolianten 83, Geheimes Staatsarchiv Preussischen Kulturbesitz (Berlin-Dahlem), Niemcy.

Kwiatkowska, Wiesława. 1991. Średniowieczne księgozbiory franciszkanów i dominikanów toruńskich jako świadectwo ich kultury umysłowej i możliwości oddziaływania na środowisko mieszczańskie. Mps rozprawy doktorskiej, Biblioteka Instytutu Informacji Naukowej i Studiów Bibliologicznych Uniwersytetu Warszawskiego.

Kwiatkowska, Wiesława. 2000. „Średniowieczna biblioteka klasztoru franciszkanów w Toruniu". Folia Torunensia 1: 9-30.

Lückerath, Carl und Benninghoven Friedrich, bearb. von. 1999. Das Kulmer Gerichtsbuch 1330-1430. Liber memoriarum Colmensis civitatis. Köln: Böhlau Verlag.

Marochitanus, Samuel, Alfonso Buenhombre, Jakob Radlinski. 1753. Prawda chrzescianska od nieprzyiaciela swego zeznana, to iest Traktat rabina Samuela pokazuiacy bledy zydowskie okolo zachowania prawa Moyzeszowego, y przyiscia Messyaszowego, ktorego Zydzi czekaia. Lublin: Drukarnia J.K.M. Coll. Soc. Jesu.

Marsilius of Inghen. 2000. "Quaestiones super quattuor libros Sententiarum. 2: Super primum, quaestiones 8-21”, ed. G. Wieland et al., Studies in the History of Christian Thought 88, ed. M. Santos Noya. Leiden: E. J. Brill.

Nowak Zenon, Hubert. 1987. „Bracia Wspólnego Życia i ich szkoła w Chełmnie (1473-1536/1545)". Zapiski Historyczne 52(4): 53-77. 
Nowak, Zenon Hubert. 1987. „Dzieje tak zwanej Akademii Chełmińskiej”. W Dzieje Chełmna. Zarys monograficzny, red. M. Biskup. Warszawa: Państwowe Wydawnictwo Naukowe.

folia Szandorowska Eliza, 1967. „Tajemnicza oficyna drukarska XV wieku”. toru Rocznik Biblioteki Narodowej 3: 321-346.

Szandorowska, Eliza. 1968. „Czy w Chełmnie nad Wisłą drukowano inkunabuły?“. Rocznik Biblioteki Narodowej 4: 23-46.

Szandorowska, Eliza. 1973. „Biblioteka i pracownia introligatorska Braci Wspólnego Życia w Chełmnie. Próba rekonstrukcji”. Rocznik Biblioteki Narodowej 9: 265-285.

Tandecki, Janusz i Zenon Hubert, Nowak. 1994. Księga czynszów fary chełmińskiej (1435-1496). Toruń: Towarzystwo Naukowe w Toruniu.

Vita sancti Yvonis episcopi persae in anglia depositi et trium eius sociorum auctore goscelino (Apud Bolland, Acta Sanctorum, Junii tom II, die 10, pag. 287). dostęp 17.01.2017. http://www.documentacatholicaomnia.eu/02m/1082-1100, Goscelinus_Cantauriensis,_Vita_Sancti_Yvonis_Persae_Episcopi,_MLT.pdf /.

Wielomski, Adam. 2011. „Teokracja ekstremistyczna Augustyna z Ankony”. Studia Erasmiana Wratislaviensia 5: 69-86.

Wolff, Adam. 1957. „Projekt instrukcji wydawniczej dla pisanych źródeł historycznych do połowy XVI wieku". Studia Źródłoznawcze 1: 155-184.

Data przesłania artykułu do Redakcji: 21 V 2017

Data akceptacji artykułu przez Redakcję: 6 VII 2017 


\section{Mateusz Superczyński}

State Archives in Toruń

e-mail: msuperczynski@torun.ap.gov.pl

ORCID ID: 0000-0002-8176-412X

Mateusz Superczyński, MA, works in the State Archive in Toruń; he graduated from the Faculty of Archival Studies and Documentation Management of Nicolaus Copernicus University in Torun (UMK). As a student he was a member of the board of the Students' Scientific Circle of Archivists. His BA dissertation titled Sources to trace the history of Torun's district of Mokre received a distinction in the SAP competition under the name of Ryszard Mienicki concerning diploma dissertations about archival subject matters. He also received the first prize for his MA dissertation titled Sources to trace the history of Torun's suburbs from the $13^{\text {th }}$ century to 1793 in the competition organized by the Society of the Lovers of Torun (ToMiTo) for the best diploma dissertations about Toruń. In the years 2012-2014 he worked in the University Archive of Nicolaus Copernicus University. He is a member of the Association of Polish Archivists and the Society of the Lovers of Torun. He is now preparing his $\mathrm{PhD}$ thesis Chancellery and archive of the city of Chelmno in the period prior to the partitions (the $13^{\text {th }}$ century - 1772) under the supervision of Prof. dr hab. Janusz Tandecki.

\section{Inventory of the parish church of Chełmno}

\section{and its library in the $15^{\text {th }}$ century}

ey words: Chełmno, church libraries, inventory, cartulary, Chełmno's parish church

ummary. This article presents the edition of the hitherto unknown inventory of Chelmno's parish church and the register of the book collection of the parish church library of the $15^{\text {th }}$ century to be found in the City Book of Chełmno - the cartulary of privileges and documents established by the notary Konrad Bitschin in 1431. The source shows the library of Chełmno's parish church as the centre of culture in the Chelmno of the $15^{\text {th }}$ century. It allows us to compare the three preserved registers of book collections of medieval Chełmno: the collection of the Franciscan monastery of the $13^{\text {th }}$ century, the collection of the parish church library and the register of the library of the Brethren of the Common Life of the end of the $15^{\text {th }}$ century. They come from different periods of time and reflect the changes in spiritual life, theology and research interests of the contemporary intellectuals of Chełmno. While the book collections of the Franciscans and the parish church reflect the spirit of the medieval Scholasticism or nominalism, the publications of the Brethren of the Common Life harbinger the Renaissance The titles provided by the city's notary allow us to identify and spot fundamental works of medieval theology, liturgy, history and philosophy. 


\section{Mateusz Superczyński}

Staatsarchiv Thorn

e-mail: msuperczynski@torun.ap.gov.pl

ORCID ID: 0000-0002-8176-412X

Mag. Mateusz Superczyński ist Mitarbeiter des Staatsarchivs in Thorn, Absolvent der Archivwissenschaft und Dokumentationsverwaltung an der Nikolaus-Kopernikus-Universität in Thorn. Während der Studien war er Mitglied des Vorstandes des Studentischen Wissenschaftskreises der Archivarinnen und Archivare. Er erhielt eine Auszeichnung für seine Bachelorarbeit Źródła do dziejów przedmieścia Torunia - Mokre [Die Quellen zur Geschichte der Vorstadt Thorns - Mocker] im Ryszard-Mienicki-Wettbewerb des Verbands der Polnischen Archivarinnen und Archivare (bewertet wurden die Diplomarbeiten zu archivarischen Themen) sowie den ersten Preis für seine Magisterarbeit Źródła do dziejów przedmieść Torunia od XIII w. do 1793 r. [Die Quellen zur Geschichte der Vorstädte Thorns seit dem 13. Jahrhundert bis 1793] im Wettbewerb der Gesellschaft der Liebhaber Thorns (Preis für die besten Diplomarbeiten über verschiedene auf Thorn bezogene Fragen). 2012-2014 war er Mitarbeiter des Archivs der Nikolaus-Kopernikus-Universität in Thorn. Er ist Mitglied des Verbands der Polnischen Archivarinnen und Archivare und der Gesellschaft der Liebhaber Thorns. Zurzeit bereitet er unter Betreuung von Prof. Janusz Tandecki seine Dissertation vor: Kancelaria i archiwum miasta Chełmna w okresie przedrozbiorowym (XIII w. - 1772 r.) [Die Kanzlei und das Archiv der Stadt Kulm vor den Teilungen Polens (13. Jh. - 1772)].

\section{Das Inventar der Kulmer Pfarrkirche und}

\section{ihre Bibliotheken aus dem 15. Jahrhundert}

Stichworte: Kulm, Kirchenbibliothek, Inventar, Kopialbuch, Kulmer Pfarrkirche

Zusammenfassung. Der vorliegende Beitrag bezieht sich auf die Edition des bisher weniger bekannten Inventars der Kulmer Pfarrkirche und des Verzeichnisses der Buchbestandes der Pfarrbibliothek aus dem 15. Jahrhundert. Die Archivalien sind im Stadtbuch Kulms, dem Kopialbuch der Privilegien und der Urkunden, angefangen 1431 vom Schreiber Konrad Bitschin, zu finden. Die Quellenüberlieferung schildert die Bibliothek der Kulmer Pfarrkirche als eines Kulturzentrums der Stadt im 15. Jahrhundert. Sie erlaubt auch, die drei erhaltenen Verzeichnisse der Buchbestände des mittelalterlichen Kulm miteinander zu vergleichen. Es handelt sich dabei um die Verzeichnisse aus dem Franziskanerkloster aus dem 13. Jahrhundert und der Pfarrbibliothek sowie das rekonstruierte Verzeichnis der Bibliothek der Brüder vom gemeinsamen Leben aus dem Ende des 15. Jahrhunderts. Sie alle stammen aus verschiedenen Epochen und schildern die Änderungen im geistigen Leben, in der Theologie und den wissenschaftlichen Interessen der zeitgenössischen intellektuellen Eliten der Stadt. Die Buchbestände der Franziskaner- bzw. der Pfarrbibliothek spiegeln den Geist der mittelalterlichen Scholastik oder des Nominalismus wider, dagegen kündigen die Ausgaben der Brüder vom gemeinsamen Leben den Humanismus an. Die vom Stadtschreiber notierten Überschriften erlauben trotz ihrer Verzerrungen, die für die mittelalterliche Theologie, Liturgie, Geschichte und Philosophie grundlegenden Werke zu identifizieren und zu analysieren. 